\title{
AN IMMERSIVE AUGMENTED REALITY SYSTEM TO STUDY THE EFFICIENCY OF DYNAMIC EXIT SIGNAGE
}

\author{
Azhar Mohd Ibrahim*, MUhammad ARIF Kamaruddin \\ AND AZNi NABEla WAHID \\ Department of Mechatronics Engineering, International Islamic University Malaysia, \\ Jalan Gombak, 53100 Kuala Lumpur, Malaysia \\ *Corresponding author: azhar_ibrahim@iium.edu.my
}

(Received: $18^{\text {th }}$ March 2021; Accepted: $5^{\text {th }}$ May 2021; Published on-line: $4^{\text {th }}$ January 2022)

\begin{abstract}
Every year, many disasters occur to buildings causing their destruction and leading to huge casualties. One way of preventing casualties is by evacuation drill activity. Although accurate evacuation drills could enhance the efficiency of the process during the real event, these drills are not fully effective because participants miss the sense of being stressed or under pressure while in action. Several gaming concepts have been introduced to train the participants on how to cope with and evacuate effectively during an emergency. For instance, Augmented Reality (AR) and Virtual Reality (VR) interfaces could provide virtual content to enhance the effectiveness of evacuation drills. However, accurate representation of different evacuation scenarios and its impact analysis during emergency using the above technologies are still debatable, mainly due to immersion quality. Thus, this study proposes an Immersive Augmented Reality (IAR) application that is mainly the amalgamation of AR and VR in realizing fast and safe evacuation during on-site building emergencies. A virtual dynamic exit signage system is also developed in the proposed "Smart Evacuation application". This work evaluated the efficiency of a virtual dynamic exit signage and also a proposed "Smart Evacuation" system by analysing on-site emergency evacuation processes. By setting up various scenarios imitating real life disasters, this research analysed the time taken and level of stress of the occupants during the evacuation of a chosen site. The proposed "Smart Evacution" achieved 33.82\% better perfomance compared to normal evacuation thus indicating a faster and safer evacuation.
\end{abstract}

ABSTRAK: Secara statistik, kebanyakan bencana kemusnahan bangunan yang berlaku setiap tahun telah menyebabkan kerugian besar. Salah satu cara bagi mengelak kejadian ini adalah melalui aktiviti latih tubi evakuasi. Walaupun latih tubi evakuasi ini dapat menambah proses kecekapan semasa kejadian sebenar, latih tubi ini tidak benar-benar berkesan kerana peserta kurang mendalami perasaan tertekan atau di bawah tekanan semasa kejadian. Pelbagai konsep permainan telah diperkenalkan bagi melatih peserta bagaimana perlu bertindak dan evakuasi secara efektif semasa kecemasan. Sebagai contoh, antarmuka Realiti Terimbuh (AR) dan Realiti Maya (VR) mungkin dapat menghasilkan simulasi secara maya bagi menambah keberkesanan latih tubi evakuasi. Walau bagaimanapun, ketepatan representasi pelbagai senario evakuasi dan analisis tekanan semasa kecemasan menggunakan teknik-teknik di atas adalah masih boleh dipertikaikan terutama kerana kualiti kedalamannya. Oleh itu, kajian ini mencadangkan aplikasi Realiti Terimbuh Mendalam (IAR) di mana tumpuan adalah pada kombinasi AR dan VR dibuat dengan secara evakuasi pantas dan selamat semasa kecemasan pada bangunan kejadian. Sistem maya penunjuk arah keluar dinamik turut dicipta dalam "Aplikasi Evakuasi Pintar" yang dicadangkan ini. Kajian ini menilai keberkesanan sistem maya penunjuk arah keluar secara dinamik dan juga sistem "Evakuasi Pintar" dengan menganalisa proses evakuasi 
kecemasan pada tempat kejadian. Dengan mengadakan pelbagai jenis senario dan meniru bencana sebenar, kajian ini menganalisa masa yang diambil dan tahap tekanan penghuni bangunan semasa proses evakuasi berlaku pada tapak pilihan. "Evakuasi Pintar" ini mencapai $33.82 \%$ keberkesanan pada prestasi berbanding evakuasi biasa. Ia membuktikan proses evakuasi ini lebih pantas dan selamat.

KEYWORDS: immersive augmented reality; dynamic exit signage; evacuation; fire building

\section{INTRODUCTION}

Signages or legends have been used in various locations to aid people in recognizing their location, for navigation, for immediate notices, and other purposes. The most crucial signage that every building should install is the exit signage that is made compulsory by the Occupational Safety and Health Administration (OSHA) and the National Fire Protection Association (NFPA). In its guideline, OSHA states that "Exit signs must be clear of decorations, equipment which may impair visibility to means of an exit. Access to exits must be marked by visible signs in all cases where the exit or way to reach it is not immediately visible to the occupants" [1]. However, most of the time during emergency situations, such as natural disaster or fire, these exit signages lose their functionality due to the damage incurred by the event that caused visual impairment to the occupants. In addition, these static signages have fixed images that are unable to react to the immediate situation, possibly causing the evacuees to choose a dangerous route. A research conducted by the Fire Safety Engineering Group of The University of Greenwich found that only $38 \%$ of evacuees saw the emergency signage during the emergency situations, which shows the low effectiveness of the sign. From those numbers, $100 \%$ of them will obey the sign immediately although they did not confirm whether the designated path is safe or not [2].

Due to the incompetence of the signage during emergency, a lot of accidents and casualties have been recorded throughout the years when the occupants were trapped, suffocated, stampeded by a panicked crowd, etc. The US Fire Administration recorded that from 2013 to 2015, the number of fire fatalities from 1800 fatal fires in residential buildings was around 2695 civilians [3]. In China, the average number of fire fatalities for each year hit around 2500 people while the fire incidents occurred around 140000 to 260000 times every year [4]. In Malaysia, it has been recorded that fire incidents occurred to 1024.67 per 1000000 population for each year between 2006-2015. Fire fatalities have been recorded at around 7.53 for each 1000000 population per year. The record also shows that there is an increasing trend of about $30 \%$ of fire victims from 2012 to 2014 [5].

One of the main problems during evacuation management is dynamic human behavior, which is unpredictable and difficult to calculate. Various researchers have done numerous experiments and data collecting from surveillance video and surveys to grasp the understanding of human behavior in crowd [6]. For safety purposes during real data collection, theoretical analysis via simulations are normally conducted to analyze unforeseen problems during the evacuation. However, the problem with simulation is that it lacks immersion and understanding of real scenarios causing varying reactions and behaviors and thus affecting the result of the studies [7-9]. Another fundamental problem during evacuation is unfamiliarity with the structure of the building, which slows down movement to the exit. The presence of legends around the building plays a big role to lead those people, however, during the real event, the visibility of the signs will be hindered and therefore misleading [10]. 
Augmented Reality has indeed served humans in improving their abilities to do tasks. The wide range of AR capabilities in various sectors shows its competency and importance to the developed community. Among those, AR plays a major role for certain industries to achieve their objectives i.e. safety inspection, hazard identification and safety training [11]. Augmented Reality (AR) interfaces could provide virtual content to enhance the effectiveness of evacuation drills. However, accurate representation of different evacuation scenarios and its impact analysis during emergencies using AR is still debatable, mainly due to immersion quality. Thus, this research aims to develop an Immersive AR application with dynamic signage function that can guide building occupants to evacuate the building faster and safely. Besides that, this research also aims to study the effect of dynamic exit signage during an emergency toward the safety of evacuees and their evacuation time by using an augmented reality approach.

Here, we reviewed four recent AR based applications related to evacuation and navigation. First, "RescueMe" gave a good approach by connecting the application into a cloud server in which any real-time situation could be updated in an instant and thus notify the user on current condition of the building. The program created a 2D map of the building, which was designed by the developer beforehand, hence the existing map offered huge benefits to the user [12]. "MARA" on the other hand, used surrounding objects to guide the user during the evacuation. For every object, there was sign or legend image overlaid onto the object which led the user toward the right direction [13]. "MARA" also used user's feedback to analyze the effectiveness of the program. This method is a good approach to collect insights of the program for later improvement. "Mixed Reality Emergency Management" used a different practice as it mainly focused on simulated agents as a guide for users to follow [14]. By directing the smartphone onto the building structure, agents emerge into the real world via the smartphone screen and the user can follow these agents straight away a safe area is reached. Lastly, "IVR SGs" emphasized on disaster simulation to evaluate the human behavior during a crisis situation [15]. "IVR SGs" developed numerous realistic hazard situations such as falling desks or rooftops, simulated fire, falling debris to obstruct a pathway, and others. These models gave users experience on how to handle different hurdles during a catastrophe. In contrast, our proposed "Smart Evacuation" will focus on the efficiency of dynamic exit signages towards different evacuation scenarios to realize a higher probability of safe and fast evacuation.

\section{METHODS}

A mobile application called "Smart Evacuation" is introduced here (as shown in Fig. 1) and will be center of the research that all the research methodologies (as shown in Fig. 2 and Fig. 3) are based on. This application was developed using "Unity3D" and mainly uses an AR during most of its operation. The program consists of several main components that function to lead the user during the evacuation process. The components of such dynamic signage will overlay onto the existing signage to show the correct route from user's position toward the destination of either a safer area or an assembly point. Figure 1 shows examples of the "Smart Evacuation" application's icon and its interface.

The "Unity 3D 2018.4.23f1" engine is used as the main medium as it has built-in navigation mesh to create a surface for simulation of the agents. The realistic looking features provided by "Unity" is also a strong advantage as the modelled object in simulation should resemble its real-life counterpart as much as possible to help the user feel familiar in the augmented world. 


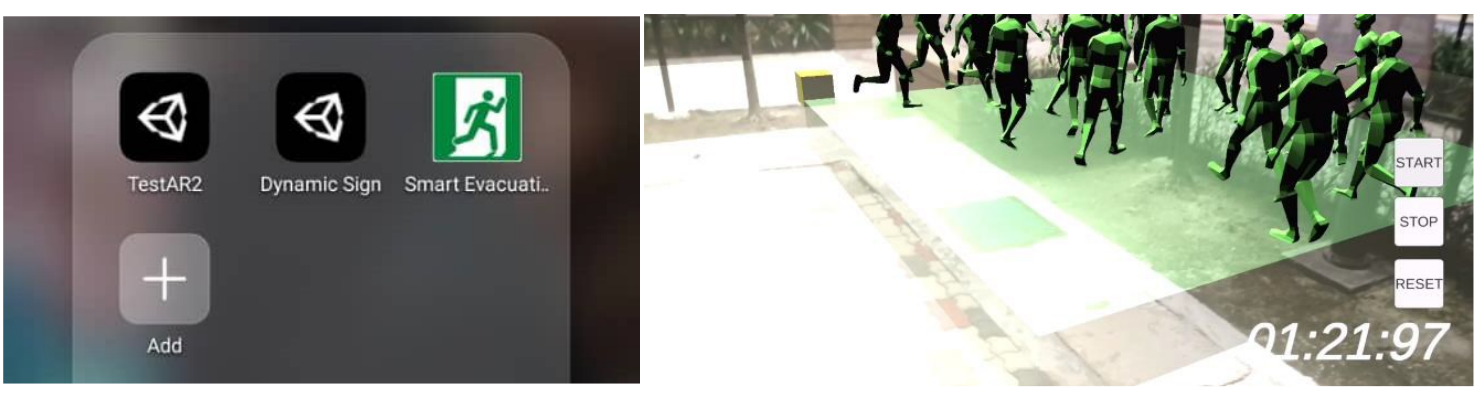

Fig. 1: Smart evacuation application.

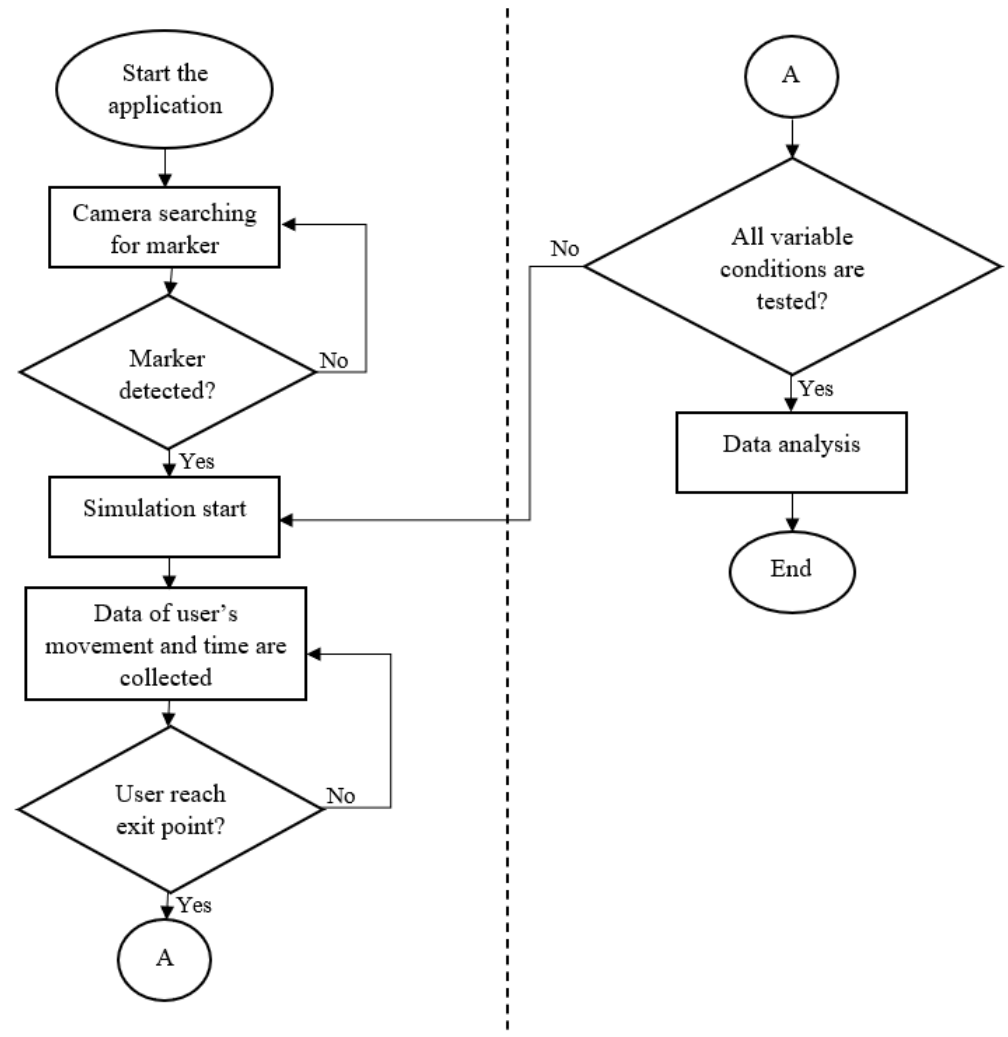

Fig. 2: Process flow of the proposed method.

For the proposed "Smart Evacuation", there are several scripts of code that determine the evacuation movement flow. All scripts are designed for different "GameObjects" (fundamental objects in "Unity") such as timer function, marker detection function for signage and defining location function, but they are correlated with each other and served as one main process flows, as depicted in Fig. 3. The "GameObjects" agents have their own flow process that is not affected by other processes. The purpose of these agents is to create a visual evacuation scenario for the user in which the user could feel as if there are other people running to the safer place during the process. When the virtual environment is synchronized, agents will be generated onto the scene. Then, agents start running to the safe area. Upon reaching the safe area, agents will be in stand still motion indicating completion of their process flow in the proposed method. Meanwhile, the whole evacuation flow will end only when the user itself reaches the safe area. 


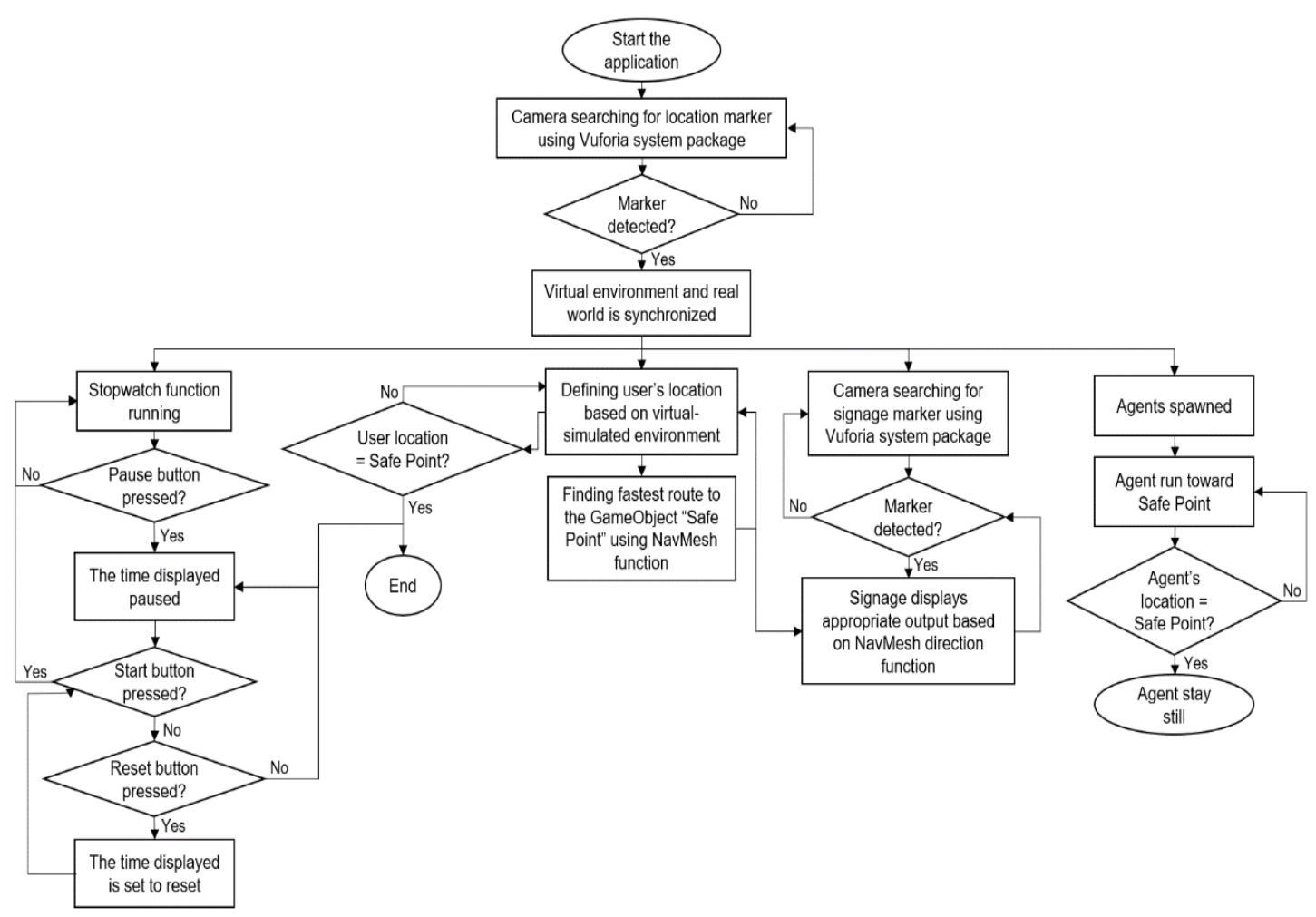

Fig. 3: Flow chart of the proposed Smart Evacuation.

\subsection{Evacuation Simulation}

To develop a realistic simulation of humans moving around the designated environment in "Unity", the pathfinding system is needed so that they only will move along to the desired path [16]. "Unity" provides two main features: Agents and Navigation Mesh. Agents are the objects that will move within the desired area while Navigation Mesh is the system that will indicate the walkable area for the agent. But before that, the environment of the simulation must be created first.

\subsubsection{Floor Plan}

Here, the simulation site used is the second floor of the E1 Engineering building in the International Islamic University Malaysia. This site has a suitable design with good movement flow and a decent amount of exit paths. The parameters of the hallways are also suited to the test where the width of the hallway is $3.44 \mathrm{~m}$, which can fit about 2 agents with $0.5 \mathrm{~m}$ of spacing between them. The size of the door is $1.81 \mathrm{~m}$, which allows one agent to pass through it at a time. For the stairs, the width of the stairs is about $1.8 \mathrm{~m}$. For the simulation, the design of the actual floor plan is modified to a simpler one due to the abundance of parts of the structure that are unrelated to the evacuation drill. The final design of the floor plan is shown in Fig. 4.

\subsubsection{Agents}

The developed Virtual Agents are designed to have similar body vectors to human bodies i.e. their movement is approximately similar to how human bodies move. They will then run according to their navigated path to imitate how normal residents would run towards the outside of the building when a disaster occurred. 


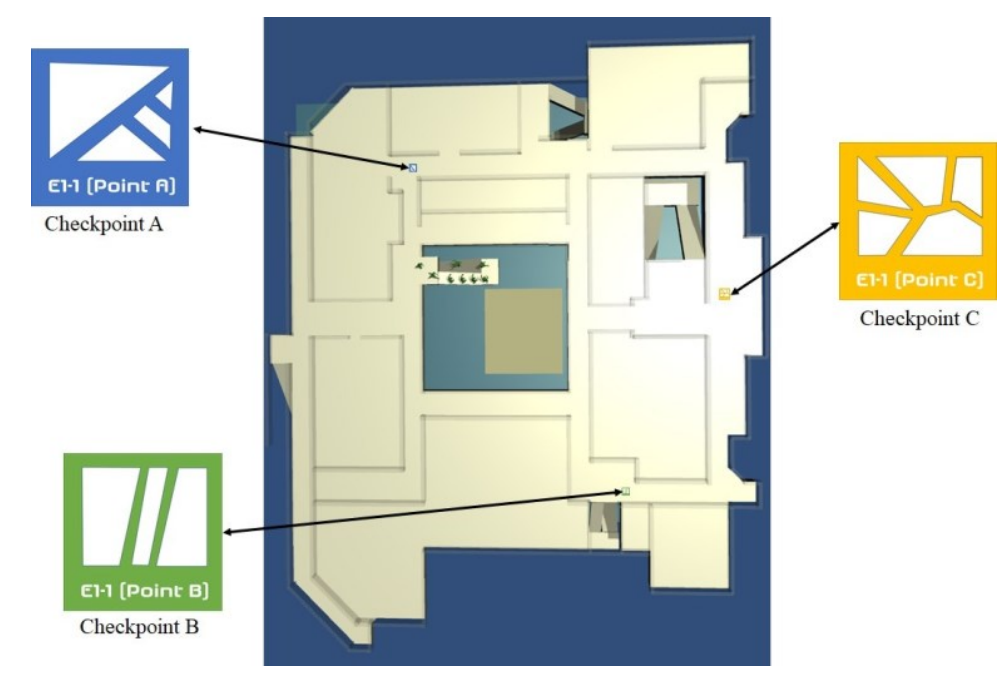

Fig. 4: Floor plan of the simulated environment according to the actual floor plan.

For the agent design, some standards had to be followed. These standards were necessary for the perfection of movement during the evacuation simulation to avoid any faults or errors, such as collisions. The standard suggested by Berg et al. [17] requires two circles around each agent; a reserved radius and a safety radius for collision avoidance purposes. All agents also should move at the same speed [17]. Thus, the agent speed is set at $1.43 \mathrm{~ms}^{-1}$ following the mean speed of human gait [18]. Figure 5 shows the "GameObject" of the agent where it is surrounded by a collider capsule, used for detecting another object that interacts with it which will trigger the programmed event. In this case, the capsule acts as collision avoidance, where the agent will stop moving if it enter another agent's parameter. The radius for the collider is $0.5 \mathrm{~m}$ while the height is set to $2 \mathrm{~m}$.

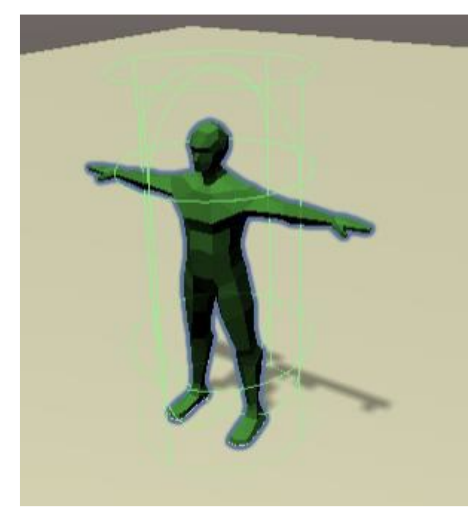

Fig. 5: Capsule collision of agent.

\subsubsection{Navigation Mesh}

Navigation Mesh is provided by "Unity" 3D to help ease the developer in creating a pathfinder in a complex space for the simulation program. The Navigation Mesh or "Navmesh" also helps automatically program the agent so that it will avoid collisions with its environment. "Navmesh" is a 2D polygon mesh that defines a walkable area for the chosen agent. Agents can only walk or pass-through "Navmesh" areas in the simulation, no other areas.

The 'baked' function will automatically create the walkable surface for the agent, but the layer must first be set to differentiate what objects in the environment will be the surface 
and what will be obstacle. After the execution of the 'baked' function, there will be a blue polygon filling up the surface, as seen in Fig. 6. In the figure, Object A is a wall (object) that agents cannot move through, that thus creates a room and hallway in the simulated environment. Area B is the limit boundaries created by "Navmesh" so that it has collision avoidance tolerance between the agent and wall. Surface $\mathrm{C}$ is the walkable area for the agent.

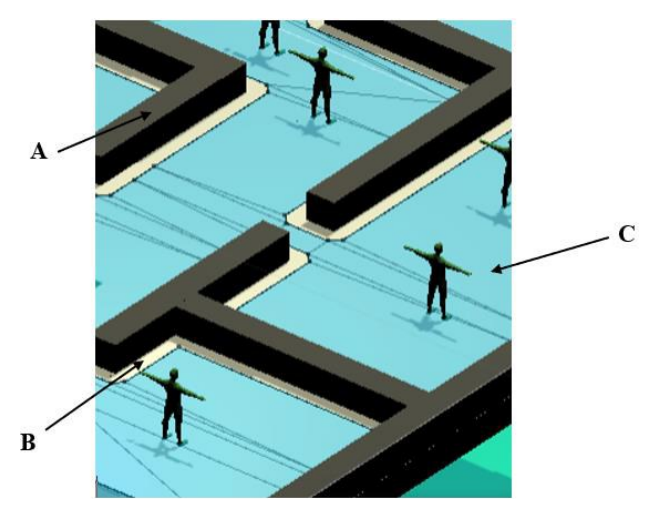

Fig. 6: 'Baked' Navmesh surface.

\subsubsection{Marker Detection}

This section will describe how the image tracking works. The processes are categorized into four phases, as shown in Fig. 7. The four phases include data collection, marker design, marker detection, and overlay process. The first phase is data collection, which is used to point out the problem on AR tracking. Pilet [19], in his research, mentioned that some features of the marker's surface that should accounted for are the geometry and texture. To make even tiny holes acceptable for the system, the continuity of the object surface must be emphasized. He also highlights that the camera angle towards the objects should be approximately 35 to 45 degrees for the determination of marker placement [19]. Thus, a marker-based type is chosen due to its ease of programming and its variety of source code that can lead to an infinity of outputs.

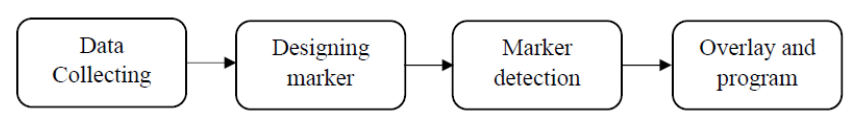

Fig. 7: Flow of image tracking phases.

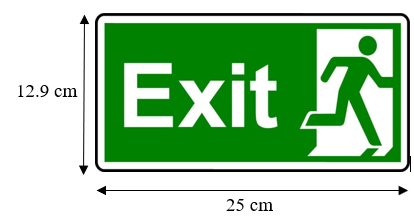

Fig. 8: Exit sign marker with dimension.

In this work, Qualcomm Vuforia Software Development Kit (SDK) is chosen as the medium to program the augmented image due to its recognition compared to other tool software. For the second phase, internal structure of the program is designed. The image marker that will be tested is an Exit Sign. This signage is a normal exit sign with the word "EXIT" and a vector of a person running in green and white color (Fig. 8). This image will be printed on a paper with dimensions of $25 \mathrm{~cm}$ width and $12.9 \mathrm{~cm}$ height and will be used for image tracking tests later.

Fiala [20] stated that markers should be in hybrid semi-rigid arrays during the execution of ARTag marker-based detection on the objects with non-rigid surfaces. Thus, to create a specified array, the placement of marker must be paired with correct the alignment onto the surface. Hence, an image splitting method is used to extract the features of the exit sign. 
Figure 9 shows how the image is extracted and the image is identified by its distinct features [20].

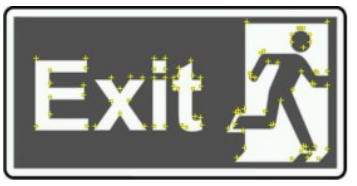

Fig. 9: The marker's features after extraction.

In phase three, the marker detection will be applied onto the surface. First, the marker will be registered into the system and the image will be saved into the system's database. The application then will give the most appropriate tracking method to detect the marker on the surface. The marker registration system is a method to define an image to be recognized by the system as an AR marker so that the application can recognize it. So, "Vuforia SDK" is an appropriate software to be used as it provides tracking features for natural feature marker-based detection. This software allows the programmer to use their own image to be the marker by storing the image as image target data in the target database of the system. Thus, this method provides unlimited input and variables for the programmers while it helps during image feature extraction by reducing the restrictions on the variety in marker representation.

Vuforia SDK is a built-in tool inside "Unity" 3D Engine software (refer Fig. 10). "Unity" will handle both the Vuforia image tracking system and AR camera functionality. The image from the extraction of the exit sign in the target database will be imported into "Unity". Then, the camera functionality will capture the image and send it to the tracker, frame by frame. The image will be converted from camera format to rendering and tracking format. Vuforia SDK tracker also has a computer vision algorithm that is able to recognize real-world objects in captured frames. Thus, from there, Vuforia is able to detect the markers from the target database and save it into the video renderer for later use.

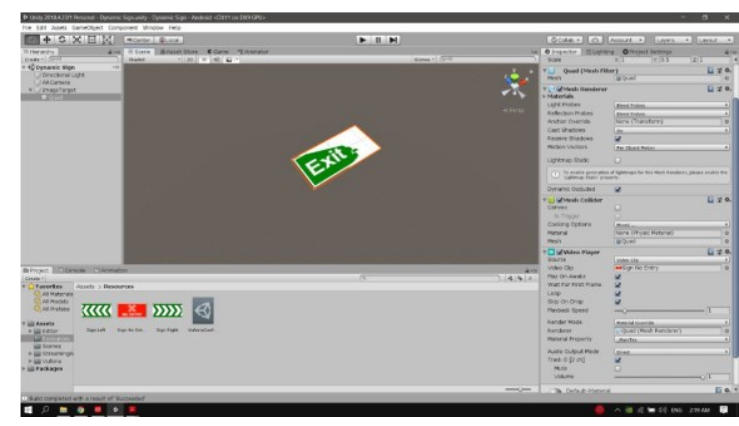

Fig. 10: "Unity" user interface with Vuforia SDK built-in.

In the last phase, the marker taken by the tracker will call the image stored in database and used it in the application code. The image is then layered by intended output layer according to the program code. Figure 11 shows some of the output layers that will aid the user in their evacuation. (a) No Entry; indicates that user should not advance onward or enter the space behind the door. This may be due to blockage from the disaster (such as fire or fallen debris) or due to the pathway onward being an unsuitable path to the safe area. (b) Go Right; indicates that user should proceed moving onto the right-side path to get to the safe area. (c) Go Left; as with Go Right, but the user should turn left. (d) Enter Here; user should enter the pathway of the sign or enter the room indicated by the sign. Finally, the application was installed into the smartphone from "Unity" software and tested and 
evaluated. There are several aspects that were evaluated to specify the condition and limitation of the AR tracking from the coded program.

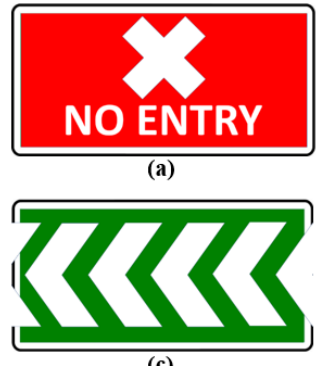

(c)
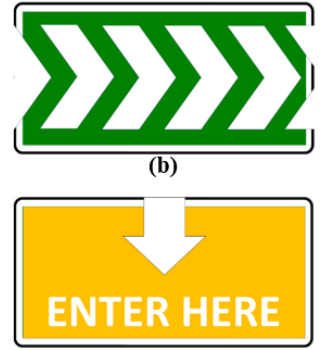

(d)

Fig. 11: Output sign of exit marker.

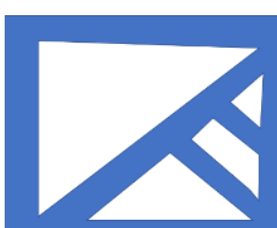

EI-1 [Point ค]

Fig. 12: Example of location detectionmarker.

\subsubsection{Location Detection Marker}

Detection marker is used for initial start-up of the simulation. Figure 12 shows one of the location detector markers. By using the image tracking method as mentioned above, the image target is registered into the database and will be called out if the AR marker detection is able to track it. Thus, the image is applied as location detection that is used to identify the user's exact location in the building. Although current smartphones have built-in GPS, use of GPS is an unreasonable approach in detecting user exact location inside the building [21].

The image tracking-based location detection method is much simpler and gives a precise position. Firstly, the image target will be set in the "Unity" software and the image will be placed in the simulation at the desired positions. The chosen positions are based on a commonly used intersection, as shown in Fig. 13, so that no matter the user's location in the building, they can go to a marker's position in the shortest time. There will be different markers on each position so the AR can identify the location. Thus, for the chosen site floor map, there will be three detection-marker locations positioned around the site with logical and strategic reasoning.

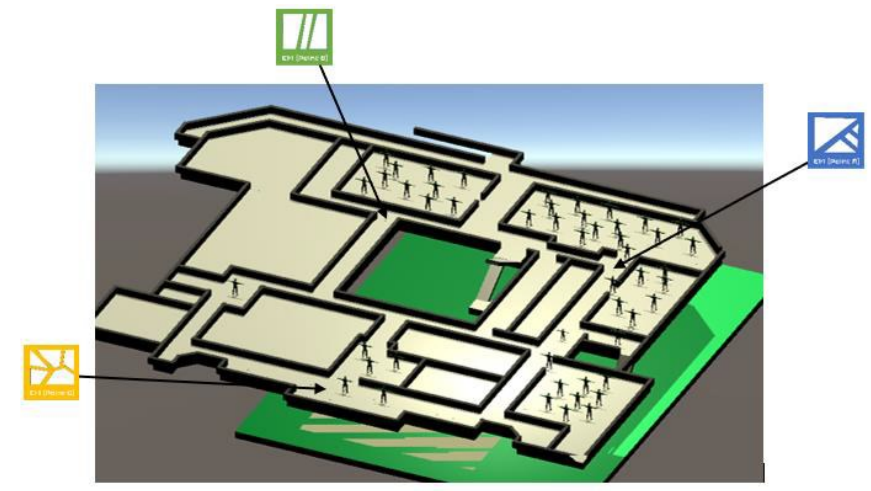

Fig. 13: The markers are placed around the building for user's convenience.

This method involves the synchronization of the marker's position between the simulation site and the real world. In "Unity", the marker is placed on the desired location. Then the real-world marker is placed on the same coordinate (refer to Fig. 14). By adjusting the scale, rotation and positioning of the marker, both markers are approximately synchronized. Thus, the wall and ground of the simulation are also synchronized with the real-world. 


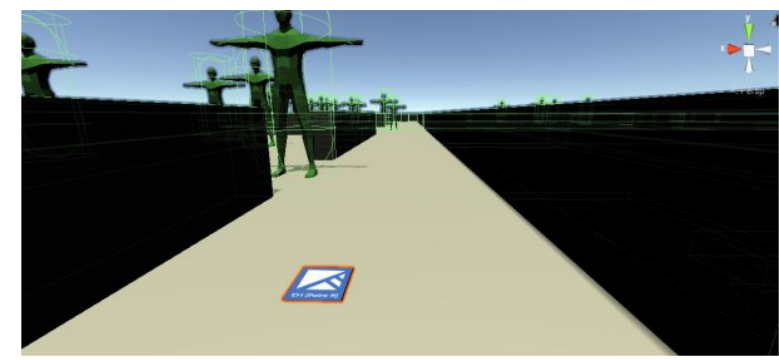

Fig. 14: The marker is placed in the simulated environment.

\subsubsection{Implementation of Dynamic Signage}

The main purpose of the dynamic signage is to lead the occupants to the exit in the fastest way possible using an optimum safe path. In a real-life situation, fire break-out can happen anywhere within the building. For fire detection, a lot of fire detectors and alarms (such as heat detectors, smoke detectors, carbon monoxide detectors) are normally installed in rooms and hallways for the maximum detection. When any of the detectors detects the fire, a signal is sent to the fire alarm control panel, and then the alarm is triggered to notify the building occupants of the fire detection.

With the implementation of dynamic signage, the building will have a different fire alarm system, shown in Fig. 15. Each of the fire detectors in the building will be assigned one identification that will determine its own precise location to the control panel. Our proposed "Smart Evacuation" aims to provide the optimum navigation to lead the user to exit the building in the safest and fastest way possible. Thus, the dynamic signage will be pre-set manually by the designer on where to lead the user throughout the building. The presence of this dynamic signage will then be compared to the evacuation without dynamic signage during the simulation. The data for both methods of evacuation will be taken for analysis.

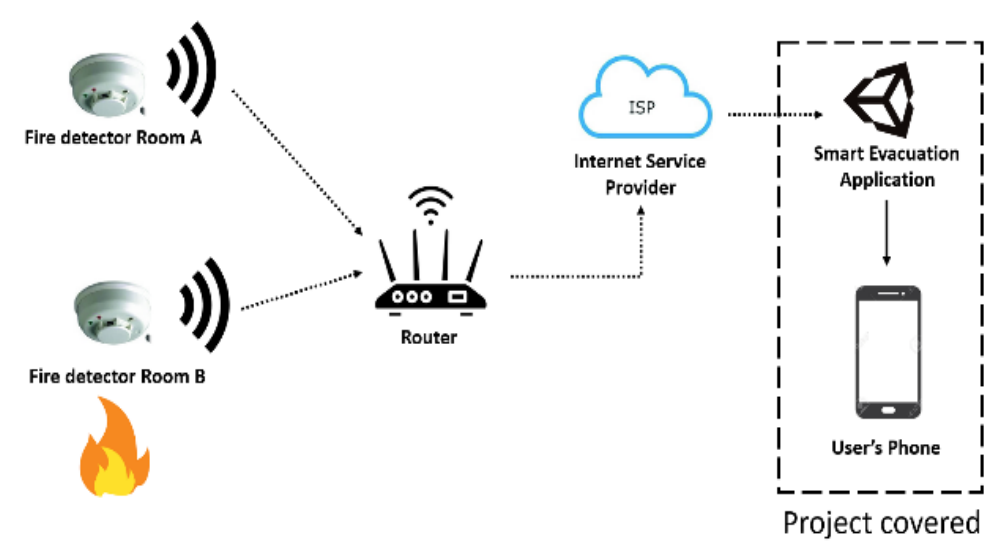

Fig. 15: Fire alarm system with dynamic signage system.

\subsection{Available Safe Egress Time (ASET) and Required Safe Egress Time (RSET)}

The Available Safe Egress Time, or ASET, and Required Safe Egress Time, or RSET, have been widely applied for fire safety assessment inside a building based on fire safety engineering design [22]. The basic idea of life safety in a building through designed safe egress is that the occupants will be safe if they are able to evacuate from the building before the fire is out of control or the space within the building is too hazardous for humans, $t_{H A Z}$. The human is expected to start the evacuation process following the detection of fire, $t_{D E T}$ 
(fire alarm) which is subsequent to the fire breaking out. Thus, ASET $=t_{\mathrm{DET}}-t_{\mathrm{HAZ}}$ can be defined as the time between the detection of the fire and the hazard condition starting to prevail [23].

RSET, on the other hand, is interpreted as the time between the detection of the fire and the time the occupant successfully evacuates from the hazardous space. Thus, the life of occupant can be ensured safe if a building has a safe design with an RSET lower than its ASET [23]. The understanding of ASET and RSET is essential for fire safety assessment of a building. This research focused solely on the movement time of the occupant following their response to the alarm until they reach the safe exit.

\section{RESULTS}

\subsection{Simulation in "Unity" Engine}

To simulate the evacuation drill in the AR based simulation, the simulation will first be tested in "Unity" to monitor the evacuation flow of the agents. Upon starting, the agents will start running to the safe area. The collider cylinder will detect nearby agents and each agent will not invade another agent's parameters; thus, they will not collide or overlap. The agents' avoidance system will slow down their movement, thus leading to agent crowds and jammed pathways, as shown in Fig. 16. This situation is similar to real-life evacuations where lots of people moving in a single space creates a congested path. The safe area or assembly point is situated on the ground floor with a big rectangular area as depicted in Fig. 17.

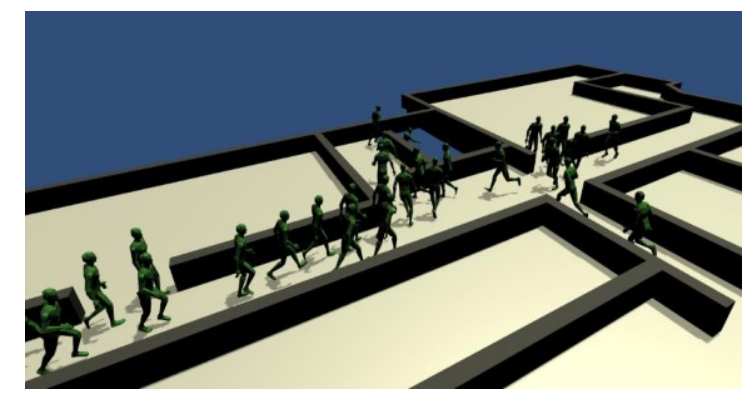

Fig. 16: Crowded area slowing the movement flow.

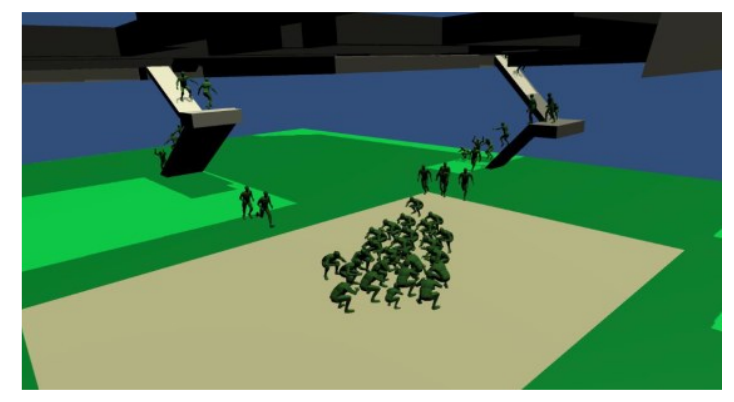

Fig. 17: Agents rushing to the safe area.

\subsection{AR Based Simulation}

To obtain the analysis of human behavior during the evacuation drill, the user should experience a situation as similar as possible to a real disaster. Thus, in this section, we will go further down to the actual AR application by using the smartphone to overlay the animated simulation into the real-world. Upon detecting the marker, the system will track the image by extracting the image features and fetching the description from the system database. Then the simulation environment, such as walls and floors, will be superimposed onto the real-world image. The real-world image is in real time as the camera is functioning and capturing the moment frame by frame.

The simulation will start automatically when the marker is detected, the user will experience the evacuation drill by seeing the virtual agents running through the real-world hallway, the fire spreading and the smoke obscuring the user's vision through the mobile app. When the animated environment is prepared and successfully overlaid, as in Figure 18, the simulation for the evacuation is ready. 


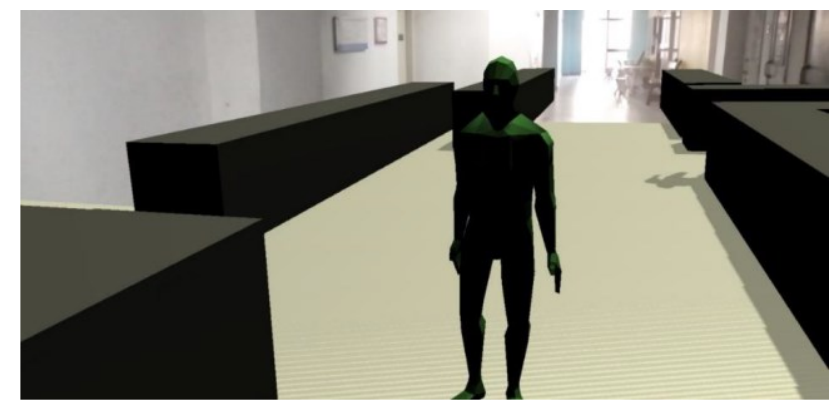

Fig. 18: Environment and agent are overlaid on the real-world image.

There are several aspects that will be evaluated in this research. The first aspect is the time taken for the evacuation. Upon starting at the location detection-marker, the user needs to go to the safe area immediately. The time will be recorded from the start of simulation until the user steps into safe area. A second aspect is the stress level of the user. The emotional strain of the users will be examined according to each area of the site. There are three checkpoints that will be analyzed, all three of which are located throughout the chosen site. For this simulation, the method of evacuation will be compared between a normal evacuation (the user will start from checkpoint and finish at the safe area without any assistance) and with AR Evacuation help (upon start, user will use the proposed application and check for the signage and follow the direction of the dynamic signage).

During the disaster, there will be numerous situations and unexpected accidents that may emerge and hinder the evacuees. Thus, in this simulation, there will be several scenarios that will be tested to evaluate on how human's reaction and behavior towards different kind of situations during the disaster. The chosen scenarios to be tested constitute the main factor contributing to fatalities during building evacuation such as low visibility, congested paths, and blocked paths.

\subsubsection{Normal Scenario}

For the first scenario, as seen in Fig. 19, there is not much additional hindrance to be put into the simulation except some of the agents running with the user. This scenario is to test the familiarity of the user toward the building's pathway and their knowledge of the evacuation path.

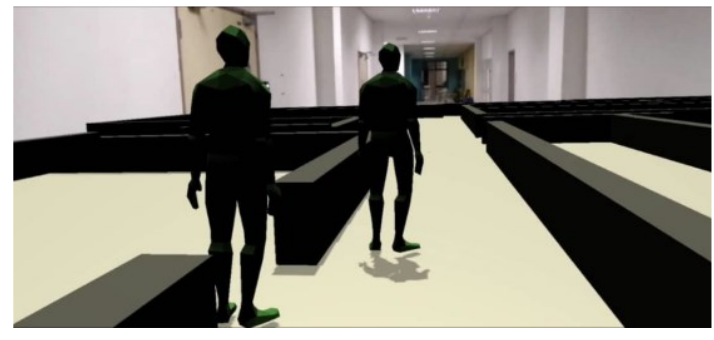

Fig. 19: Normal scenario with no additional obstacle.

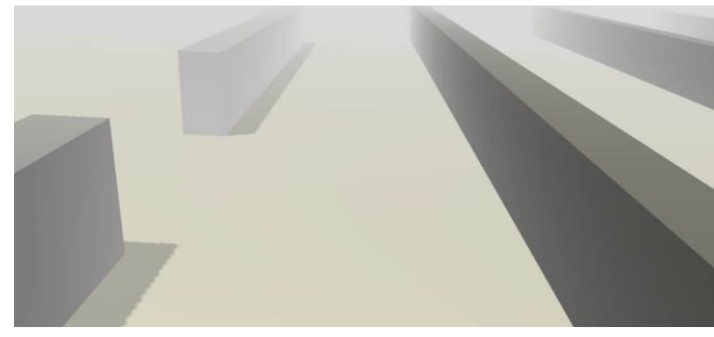

Fig. 20: Hazy environment causing low visibility to the user.

\subsubsection{Low Visibility}

For this scenario, the user will experience the low visibility problem (refer to Fig. 20). This is to resemble the smoke that emerges during the fire in the building. Besides the exposure of toxicity in the smoke, the high density level of the smoke can also lower people's visibility, thus making them harder to find the correct exit route [24]. The time taken, movement flow, and the level of stress of user will all be recorded. 


\subsubsection{Congested Path}

This scenario is similar to the first scenario except that there are an additional 40 agents in the simulation. This high number of agents is to create a heavily congested pathway such as in Fig. 21, which is one of the main factors that slow people down when evacuating the building [3]. This scenario is to test on how the user will adapt and think critically on how to figure out the optimum path when each pathway is congested with agents.

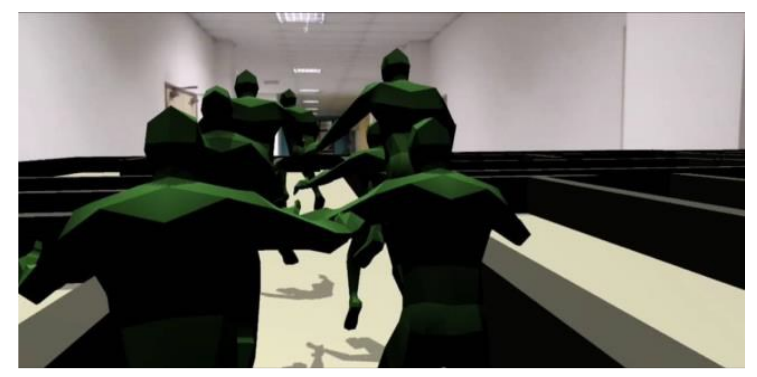

Fig. 21: Congested path scenario.

\subsubsection{Blocked Path}

The path blockage scenario is one of the common incidents that can occur during fire breakout in a building. There will be some paths that are filled with fire and wreckage of the building, which could fully block and limit the evacuation route (refer Fig. 22). This test will evaluate how the user finds the available route when most of the paths are sealed off.

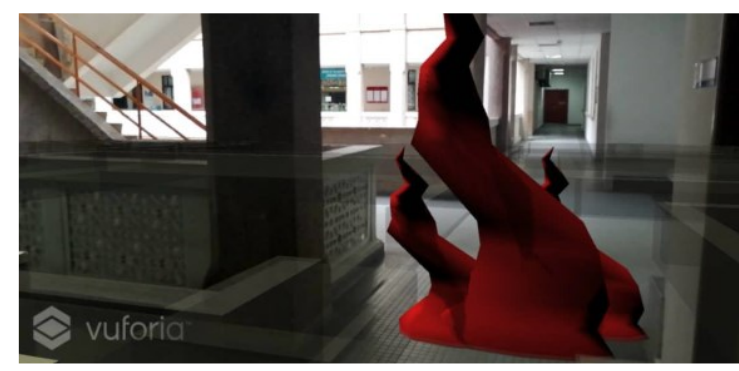

Fig. 22: Fire blocking the user from using a route.
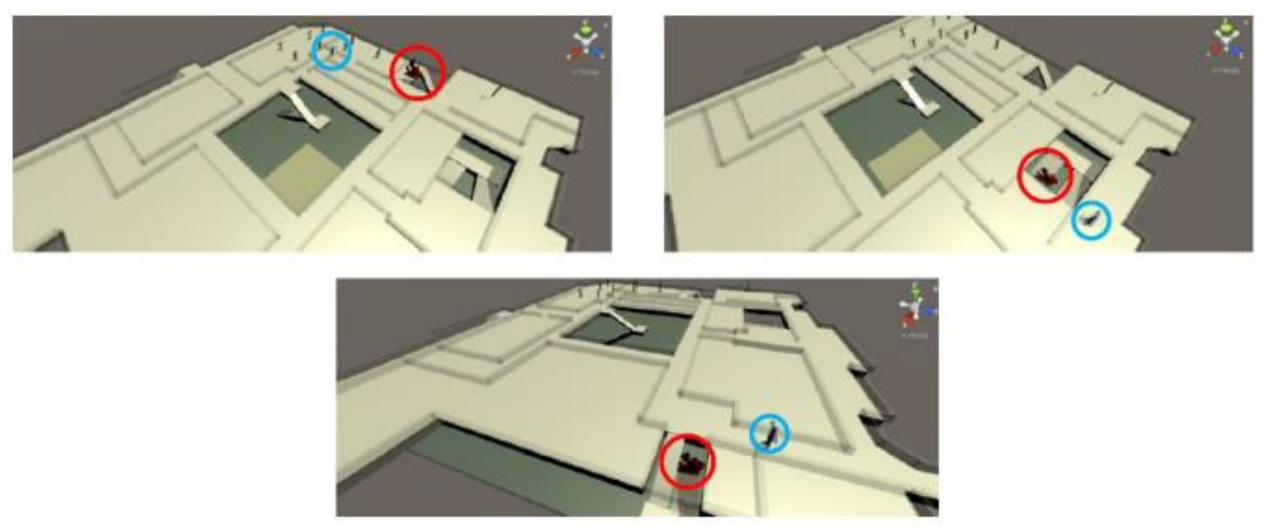

Fig. 23: Location of fire in Blocked Path scenario.

There are 3 different fire locations that will block the user's path relative to the starting point of the user. The location of fire (red circle) and the user's respective starting point (blue circle) are as seen in Fig. 23. 


\subsection{Participants}

The experimental test will be done by three participants all of whom are 23 years old. All three participants are male with similar height and normal healthy bodies. So, the speed of each participant walking is approximately same. The value taken from the participants then will be averaged for the further analysis.

\subsection{Time Taken}

Time taken will start when the location detection-marker is detected and will stop when the user reaches the safe area. The results are shown in Table 1 below.

Table 1: Result for time taken for user to reach safe point (Please refer Fig. 3 for the location of Checkpoint A, B and C). The time unit is minute (m): second (s): millisecond (ms).

Normal Scenario

\begin{tabular}{|c|c|c|c|c|c|c|}
\hline & \multicolumn{2}{|c|}{ Checkpoint A } & \multicolumn{2}{|c|}{ Checkpoint B } & \multicolumn{2}{|c|}{ Checkpoint C } \\
\hline & $\begin{array}{c}\text { Normal } \\
\text { Evacuation } \\
\text { (m:s:ms) }\end{array}$ & $\begin{array}{l}\text { With AR } \\
\text { (m:s:ms) }\end{array}$ & $\begin{array}{c}\text { Normal } \\
\text { Evacuation } \\
\text { (m:s:ms) }\end{array}$ & $\begin{array}{l}\text { With AR } \\
\text { (m:s:ms) }\end{array}$ & $\begin{array}{c}\text { Normal } \\
\text { Evacuation } \\
\text { (m:s:ms) }\end{array}$ & $\begin{array}{l}\text { With AR } \\
\text { (m:s:ms) }\end{array}$ \\
\hline Participant 1 & $00: 35: 84$ & $00: 39: 93$ & $00: 31: 75$ & $00: 32: 36$ & $00: 50: 97$ & $00: 46: 18$ \\
\hline Participant 2 & $00: 37: 49$ & $00: 38: 13$ & $00: 40: 60$ & $00: 40: 25$ & $00: 48: 37$ & $00: 45: 20$ \\
\hline Participant 3 & 00:34:08 & $00: 30: 45$ & 00:38:95 & $00: 34: 52$ & 00:52:01 & $00: 45: 45$ \\
\hline Average & 00:35:80 & 00:36:17 & 00:37:10 & 00:35:71 & 00:50:45 & 00:45:61 \\
\hline
\end{tabular}

$\underline{\text { Low Visibility }}$

\begin{tabular}{ccccccc}
\hline & \multicolumn{2}{c}{ Checkpoint A } & \multicolumn{2}{c}{ Checkpoint B } & \multicolumn{2}{c}{ Checkpoint C } \\
\cline { 2 - 7 } & $\begin{array}{c}\text { Normal } \\
\text { Evacuation } \\
\text { (m:s:ms) }\end{array}$ & $\begin{array}{c}\text { With AR } \\
\text { (m:s:ms) }\end{array}$ & $\begin{array}{c}\text { Normal } \\
\text { Evacuation } \\
\text { (m:s:ms) }\end{array}$ & $\begin{array}{c}\text { With AR } \\
\text { (m:s:ms) }\end{array}$ & $\begin{array}{c}\text { Normal } \\
\text { Evacuation } \\
\text { (m:s:ms) }\end{array}$ & $\begin{array}{c}\text { With AR } \\
\text { (m:s:ms) }\end{array}$ \\
\hline Participant 1 & $00: 31: 71$ & $00: 38: 89$ & $00: 29: 58$ & $00: 34: 79$ & $00: 46: 82$ & $00: 41: 32$ \\
Participant 2 & $00: 32: 25$ & $00: 30: 58$ & $00: 29: 92$ & $00: 29: 92$ & $00: 39: 84$ & $00: 44: 65$ \\
Participant 3 & $00: 38: 34$ & $00: 34: 01$ & $00: 30: 84$ & $00: 36: 15$ & $00: 42: 04$ & $00: 40: 97$ \\
Average & $\mathbf{0 0 : 3 4 : 1 0}$ & $\mathbf{0 0 : 3 4 : 4 9}$ & $\mathbf{0 0 : 3 0 : 1 1}$ & $\mathbf{0 0 : 3 3 : 6 2}$ & $\mathbf{0 0 : 4 2 : 9 0}$ & $\mathbf{0 0 : 4 2 : 3 1}$ \\
\hline
\end{tabular}

$\underline{\text { Blocked Path }}$

\begin{tabular}{ccccccc}
\hline & \multicolumn{2}{c}{ Checkpoint A } & \multicolumn{2}{c}{ Checkpoint B } & \multicolumn{2}{c}{ Checkpoint C } \\
\cline { 2 - 7 } & $\begin{array}{c}\text { Normal } \\
\text { Evacuation } \\
\text { (m:s:ms) }\end{array}$ & $\begin{array}{c}\text { With AR } \\
\text { (m:s:ms) }\end{array}$ & $\begin{array}{c}\text { Normal } \\
\text { Evacuation } \\
\text { (m:s:ms) }\end{array}$ & $\begin{array}{c}\text { With AR } \\
\text { (m:s:ms) }\end{array}$ & $\begin{array}{c}\text { Normal } \\
\text { Evacuation } \\
\text { (m:s:ms) }\end{array}$ & $\begin{array}{c}\text { With AR } \\
\text { (m:s:ms) }\end{array}$ \\
\hline Participant 1 & $01: 29: 72$ & $1: 10: 25$ & $02: 20: 75$ & $01: 34: 57$ & $02: 08: 35$ & $01: 28: 12$ \\
Participant 2 & $01: 33: 65$ & $1: 04: 76$ & $01: 39: 87$ & $01: 35: 35$ & $01: 42: 15$ & $01: 39: 98$ \\
Participant 3 & $01: 33: 22$ & $1: 02: 84$ & $02: 46: 52$ & $01: 44: 58$ & $02: 06: 65$ & $01: 38: 02$ \\
Average & $\mathbf{0 1 : 3 2 : 5 3}$ & $\mathbf{0 1 : 0 5 : 9 5}$ & $\mathbf{0 2 : 1 5 : 7 1}$ & $\mathbf{0 1 : 3 8 : 1 7}$ & $\mathbf{0 1 : 5 9 : 0 5}$ & $\mathbf{0 1 : 3 5 : 3 7}$ \\
\hline
\end{tabular}

Congested Path

\begin{tabular}{ccccccc}
\hline & \multicolumn{2}{c}{ Checkpoint A } & \multicolumn{2}{c}{ Checkpoint B } & \multicolumn{2}{c}{ Checkpoint C } \\
\cline { 2 - 7 } & $\begin{array}{c}\text { Normal } \\
\text { Evacuation } \\
\text { (m:s:ms) }\end{array}$ & $\begin{array}{c}\text { With AR } \\
\text { (m:s:ms) }\end{array}$ & $\begin{array}{c}\text { Normal } \\
\text { Evacuation } \\
\text { (m:s:ms) }\end{array}$ & $\begin{array}{c}\text { With AR } \\
\text { (m:s:ms) }\end{array}$ & $\begin{array}{c}\text { Normal } \\
\text { Evacuation } \\
\text { (m:s:ms) }\end{array}$ & $\begin{array}{c}\text { With AR } \\
\text { (m:s:ms) }\end{array}$ \\
\hline Participant 1 & $00: 39: 74$ & $00: 36: 53$ & $00: 34: 99$ & $00: 29: 12$ & $00: 42: 82$ & $00: 37: 39$ \\
Participant 2 & $00: 25: 31$ & $00: 37: 15$ & $00: 36: 49$ & $00: 33: 41$ & $00: 37: 17$ & $00: 41: 58$ \\
Participant 3 & $00: 28: 56$ & $00: 25: 24$ & $00: 27: 30$ & $00: 29: 27$ & $00: 46: 88$ & $00: 42: 28$ \\
Average & $\mathbf{0 0 : 3 1 : 2 0}$ & $\mathbf{0 0 : 3 2 : 9 7}$ & $\mathbf{0 0 : 3 2 : 9 3}$ & $\mathbf{0 0 : 3 0 : 6 0}$ & $\mathbf{0 0 : 4 2 : 2 9}$ & $\mathbf{0 0 : 4 0 : 4 2}$ \\
\hline
\end{tabular}

\subsection{Level of Stress}

To calculate the level of stress for each scenario, the user will be immediately asked some questionnaire (refer to Appendices A and B) after completing the experimental test. 
The survey will be used to evaluate the level of stress upon going through the evacuation drill. The survey is based on the System Usability Scale (SUS) format where the answer ranges from (1) calm to (5) stress. The value of the response from all the question will be averaged to obtain the level of stress of the users (refer Table 2).

Table 2: Result data for level of stress analysis

\begin{tabular}{|c|c|c|c|c|c|}
\hline \multicolumn{2}{|c|}{ Scenario } & \multirow{2}{*}{$\begin{array}{c}\text { Participant } 1 \\
1.40\end{array}$} & \multirow{2}{*}{$\frac{\text { Participant } 2}{1.00}$} & \multirow{2}{*}{$\frac{\text { Participant } 3}{2.80}$} & \multirow{2}{*}{$\begin{array}{c}\text { Average } \\
1.73\end{array}$} \\
\hline Normal & Normal & & & & \\
\hline Scenario & $\begin{array}{c}\text { Evacuation } \\
\text { With AR }\end{array}$ & 1.33 & 1.00 & 2.33 & 1.55 \\
\hline Low & Normal & 2.20 & 1.60 & 3.60 & 2.47 \\
\hline Visibility & $\begin{array}{c}\text { Evacuation } \\
\text { With AR }\end{array}$ & 1.83 & 1.16 & 2.00 & 1.66 \\
\hline $\begin{array}{l}\text { Blockage } \\
\text { Path }\end{array}$ & $\begin{array}{c}\text { Normal } \\
\text { Evacuation }\end{array}$ & 3.80 & 2.60 & 4.00 & 3.47 \\
\hline & With AR & 2.17 & 1.67 & 3.00 & 2.28 \\
\hline Jammed & Normal & 1.60 & 2.60 & 3.00 & 2.40 \\
\hline & With AR & 1.50 & 1.83 & 2.33 & 1.89 \\
\hline
\end{tabular}

\section{DISCUSSION}

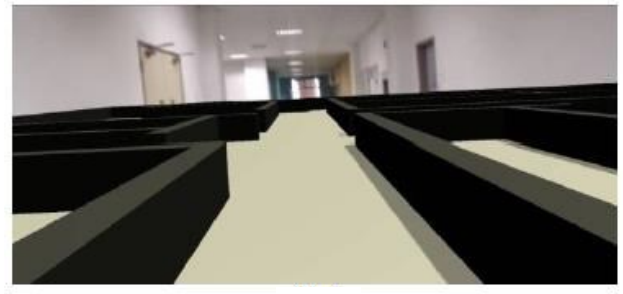

(a)

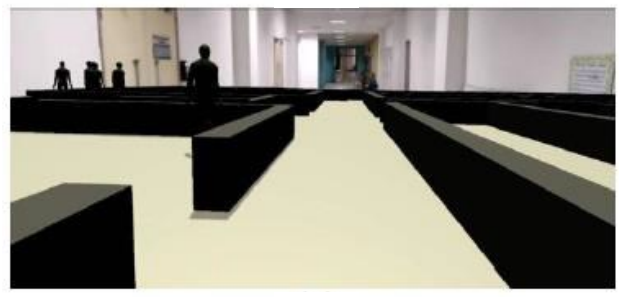

(c)

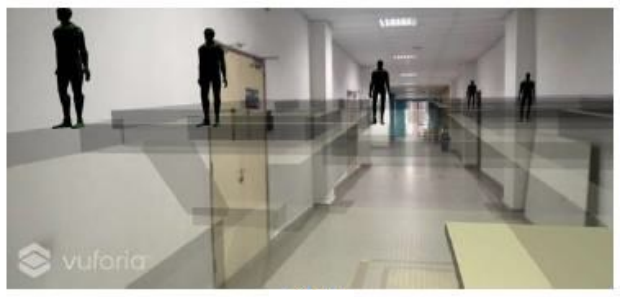

(b)

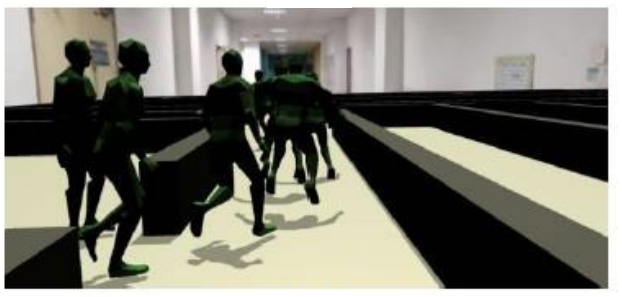

(d)

Fig. 24: Various output of agents upon detecting marker.

Upon detecting the image, the application will superimpose the virtual simulation onto the real world in less than 1 second. The walls, ground, and agents are placed onto the scene and approximately synchronized with the real world's environment. The agents are randomly generated onto the scene although during the simulation in "Unity", the agents are perfectly spawned in their programmed locations and start running to safe area. During the AR simulation, there are four situations imposed during the initial start-up of the simulation, which can be seen in Fig. 24: (a) No agent is generated on the scene. (b) The agents are spawned but in wrong place (on the wall, in the sky, etc.). (c) Agents spawned on the right position, but their movement is wrong or there is no movement at all. (d) Perfect simulation where agents are spawned correctly and move according to the program. The 
inconsistency of the agents spawned is related to how the camera is positioned during marker detection. Thus, the user needs to rescan the marker until that fourth case is obtained.

From simulation results for each scenario, the different values indicate how it affects the users differently. For the time taken to finishing the simulation, the average times taken for the participants are shown Figs. 25 and 26.

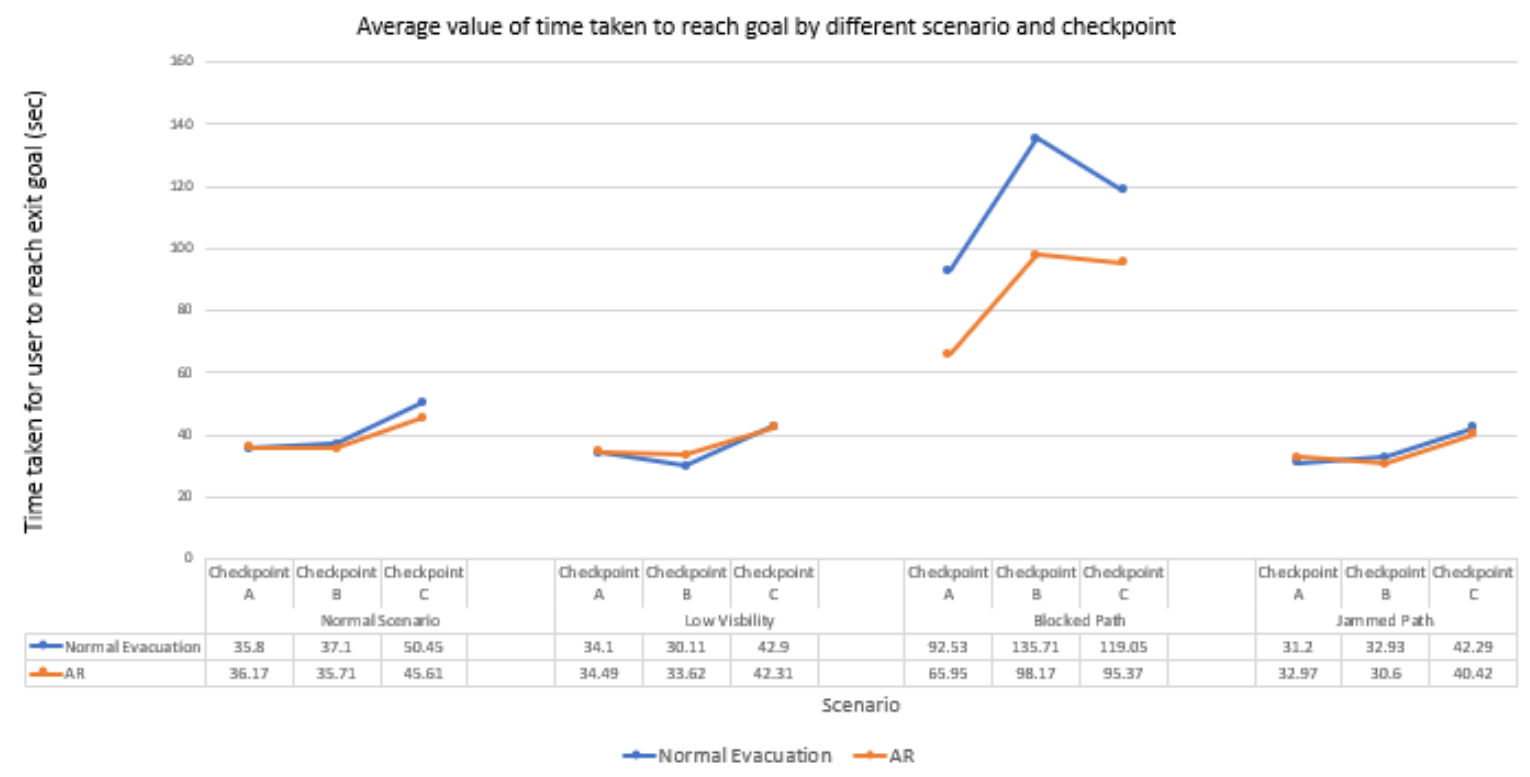

Fig. 25: Average time taken for user to reach the safe area.

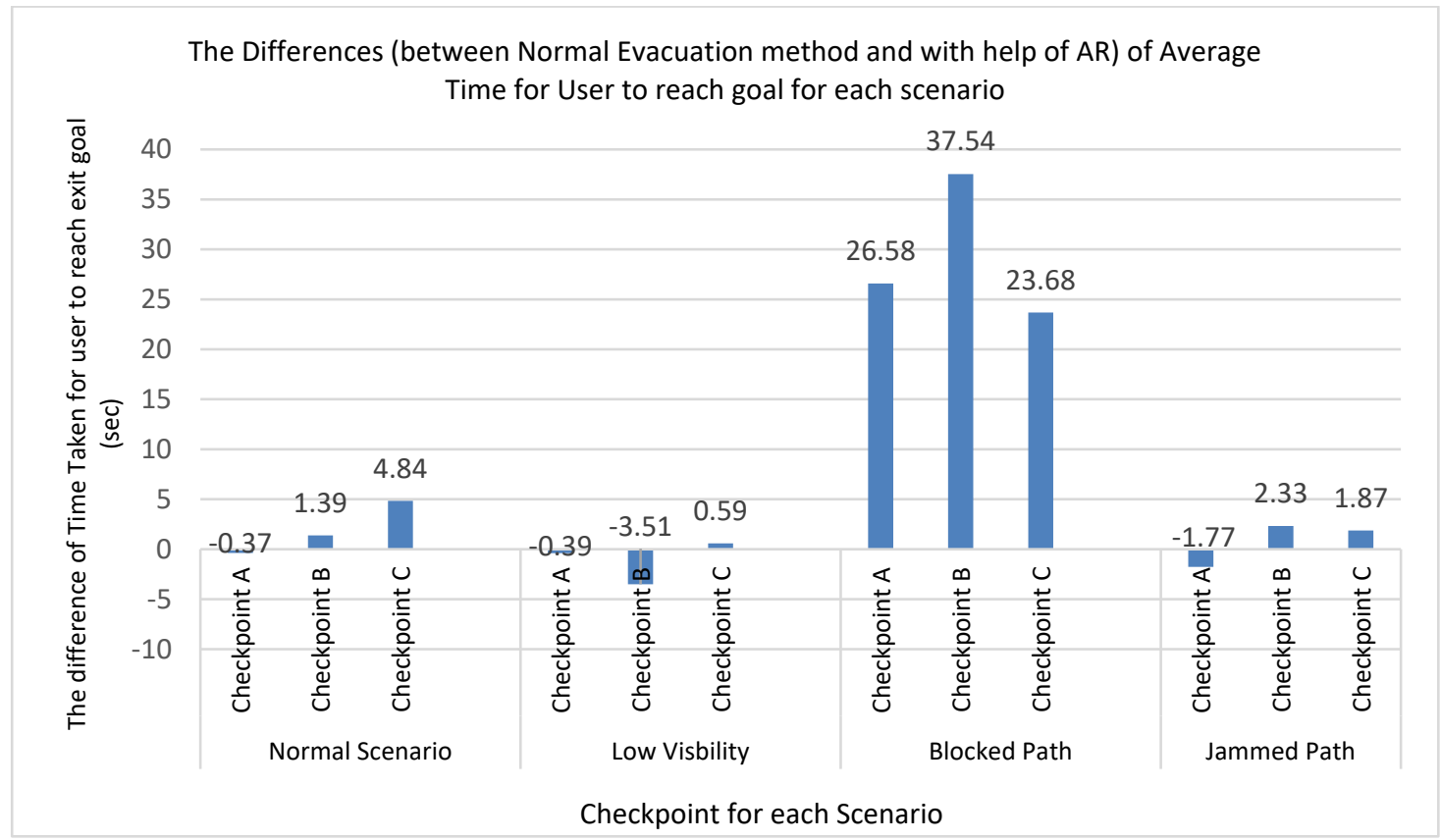

Fig. 26: Differences between normal evacuation method and with AR Evacuation method.

For a normal scenario, the time difference between the normal evacuation method versus the "Smart Evacuation" application is small. This is due to the high familiarity level of the three participants toward the simulation site i.e. they are aware of the fastest route to the safe area, which led them to use the same route that proposed by the AR without any difficulty. For the low visibility scenario, as the simulation of smoke was only displayed in 
the phone screen, participants could still see the real-world route that was still clear without any smoke. This scenario also leads to the same result as our first scenario where the differences of time for each checkpoint are relatively small. The jammed path scenario also faced a similar situation as the packed agents in the simulation did not affect the participants as the small screen of phone could not affect the human's wide field of view. The participants still see the clear real-world's hallway without any agents, as illustrated in the Fig. 27.

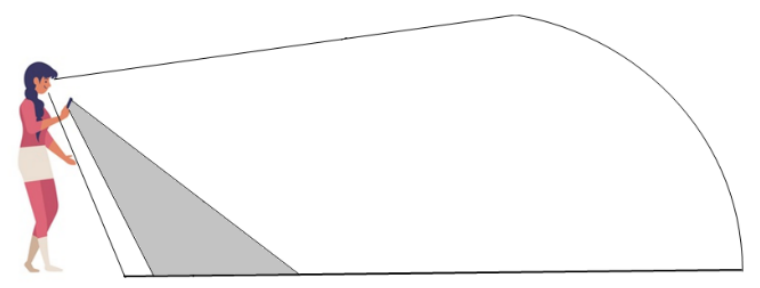

Fig. 27: Human field of vision (white) versus area covered by smartphone (grey).

For these types of scenarios, it is best for the participant to use AR head gear, so the user's field of vision is fully enclosed with the AR display. Lastly, for the blocked path scenario, we can see the huge differences in the time taken which using the 'Smart Evacuation" application led the participant faster to the exit compared to the normal evacuation method. Although the high level of familiarity of the participants toward the site simulation, they did not anticipate the location of simulated fire that blocked their path thus leading them onto the wrong path and making several turns to reach the safe area. With the big gap of differences in time between the two methods, this proved that the "Smart Evacuation" application was a huge help to lead the user to safe area faster. In general, the efficiency of the Smart Evacuation application can be calculated as

$$
\text { Performance }=\frac{1}{\text { Execution time }} \text {. }
$$

The performance value is then ratioed between the two methods; Normal evacuation and evacuation with Smart Evacuation application.

$$
\% \text { Performance }=\frac{\text { Actual performance }}{\text { Possible performace }} \times 100
$$

Taken from blocked path scenario data in Table 1, the average time taken for three checkpoints for normal evacuation and evacuation with Smart Evacuation apps are 115.76s and $86.50 \mathrm{~s}$, respectively. The performance of both can be calculated with Equation (1), thus we obtain 0.008639 and 0.011561 respectively. Equation (2) is used to calculate the efficiency of the Smart Evacuation compared to normal evacuation,

$$
\begin{aligned}
\text { Efficiency of Smart evacuation performance }= & \frac{0.011561}{0.008639} \times 100 \\
& =133.82 \%
\end{aligned}
$$

Thus, for the blocked path scenario, Smart Evacuation has a $33.82 \%$ better performance compared to normal evacuation.

On the other hand, for level-of-stress analysis (refer to Fig. 28), the "Smart Evacuation" application proved to give less stress to the user compared to the normal evacuation method. With the range of 5 from 1 (calm), 2 (somewhat calm), 3 (normal), 4 (somewhat stress) and 5 (stress), the average level of stress for the normal scenario, low visibility, blocked path, and jammed path with help of AR is $1.55,1.6,2.28$, and 1.89 respectively, which are lower than the normal evacuation method $(1.73,2.47,3.47$, and 2.4 , respectively). This 
demonstrates that the "Smart Evacuation" application aids in lowering the stress of the user during the emergency evacuation.

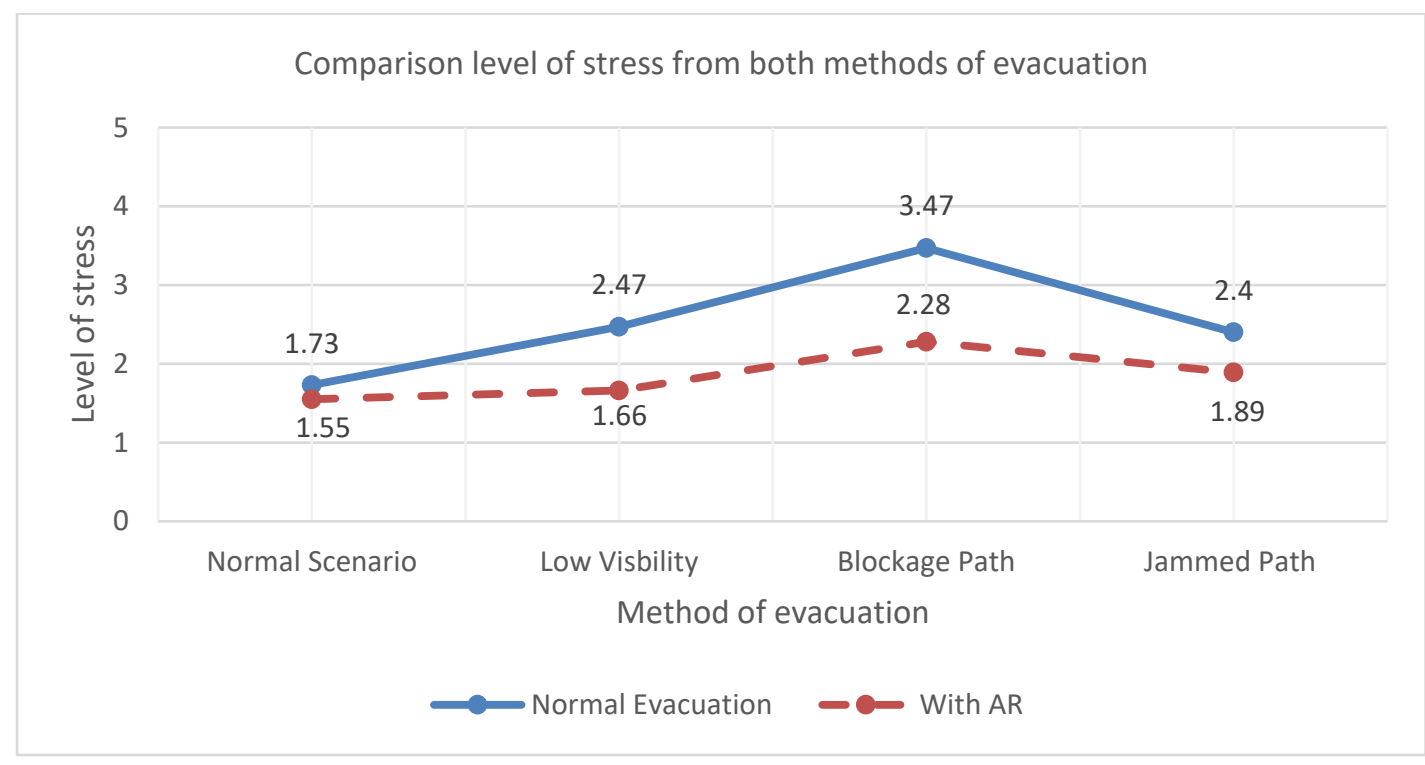

Fig. 28: Differences in stress level between the two methods of evacuation.

\section{CONCLUSION}

This research proposed an Immersive Augmented Reality (IAR) application for assisting in the evacuation process during building emergencies. With the inclusion of virtual dynamic exit signage, the performed simulation was able to give the desired result for data analysis on human behavior during evacuation drills. During the progression of the research, there are some limitations and flaws that can be pointed out in this study. The limitation of the materials in studying human behavior gives a big impact in obtaining an accurate result. For example, the unavailability of devices and programs for level-of-stress readings for the simulation's user causes the developer to use alternate methods that depend on survey and questionnaire data. Based on the result data obtained after the simulation, there are still many flaws in the result due to the incompetence of various factors during the research. Overall, the implementation of augmented reality of dynamic signage still gives a distinct outcome for some cases, which proves the efficiency of the proposed method. The main application of this proposed "Smart Evacuation" is that it can be used for real-life onsite emergency situations in assisting evacuees to reach a safer area faster. Besides that, the proposed application can also be used for on-site evacuation training purposes. Furthermore, the authority of a building can use the proposed application in analyzing movement time for the calculation of RSET, which can be used for the Fire Safety Assessment of the building.

The causes of error in the simulation results are as follows:

I. Asynchronization of the simulation world with the real world due to a small margin of error in the placement of the marker.

II. Poor built-in motion tracker of the device that could not detect the floor and the wall of the real world perfectly.

III. Agent placement error on the Navmesh surface that causes the agent to start moving weirdly.

IV. Lighting issues during the signage scanning. 
V. The familiarity of the user with the chosen site did not much affect some testing scenarios such as the smoke scenario, the normal scenario, and the jammed path scenario.

For future work, the errors above could be restored and some possible improvements that could be made include:

I. Readjusting the location detection-marker and considering the perspective view where the far object will be seen as smaller.

II. Recheck every agent on the simulation site so that its collision detection does not overlap.

III. Use a more complex building for the simulation test so the difference between each scenario will be much noticeable.

IV. Use of AR device headgear so that the user will have $100 \%$ field of vision based on the AR display.

V. Use of a variety of participants with different heights, backgrounds, or ages.

\section{ACKNOWLEDGEMENT}

This research is supported by the FRGS 2019 Grant: FRGS/1/2019/ICT02/UIAM/02/2 awarded by the Ministry of Education Malaysia and the IRAGS 2018 Grant: IRAGS18-0140015 awarded by the International Islamic University Malaysia.

\section{REFERENCES}

[1] ESW exit sign warehouse. Available: https://www.exitsignwarehouse.com/pages/exit-signregulations-requirements.

[2] Hui X, Galea ER, Lawrence PJ (2014). Experimental and survey studies on the effectiveness of dynamic signage systems. Fire Safety Science, 11: 1129-1143. doi: 10.3801/IAFSS.FSS.111129.

[3] Civilian fire fatalities in residential buildings (2008-2010). Available: https://nfa.usfa.fema.gov/downloads/pdf/statistics/v13i1.pdf.

[4] Wang F, Lu S, Li C (2005). Analysis of fire statistics of China: Fire frequency and fatalities in fires. In Proceedings of the eighth international symposium on fire safety science, IAFSS: 353362. doi: 10.3801/IAFSS.FSS.8-353.

[5] Tan YR, Akashah FW, Mahyuddin N (2012). The analysis of fire losses and characteristics of residential fires based on investigation data in Selangor. In MATEC Web of Conferences, 66: 00109.

[6] Kinateder M, Wirth TD, Warren WH (2018). Crowd dynamics in Virtual Reality. Crowd Dynamics, 1: 15-36.

[7] Warren WH (2018). Collective motion in human crowds. Current directions in psychological science, 27(4): 232-240.

[8] Nizam M, Ibrahim AM (2020). Augmented Reality-Based Evacuation Simulation To Study Crowd Behaviors. International Journal of Advanced Research in Engineering and Technology (IJARET), 11(10): 374-383.

[9] Ibrahim AM, Saifullah M, Romlay MRM, Venkat I (2019). Hybrid Social Force-Fuzzy Logic Evacuation Simulation Model for Multiple Exits. In 2019 7th International Conference on Mechatronics Engineering (ICOM): 1-5.

[10] Chen X (2006). Microsimulation of evacuation strategies. Ph.D. thesis, Texas State University San Marcos.

[11] Li X, Yi W, Chi HL, Wang X, Chan APC (2018). A critical review of virtual and augmented reality (vr/ar) applications in construction safety. Automation in Construction, 86: 150-152.

[12] Ahn J, Han R (2012). An indoor augmented-reality evacuation system for the Smartphone using personalized Pedometry. Human-Centric Computing and Information Sciences, 2(1): 1-23. 
doi: $10.1186 / 2192-1962-2-18$.

[13] Stigall J, Sharma S (2019). Evaluation of mobile augmented reality application for building evacuation. In Proceedings of 28th International Conference, 64: 109-118.

[14] Lochhead I, Hedley N (2019). Mixed reality emergency management: bringing virtual evacuation simulations into real-world built environments. International journal of digital earth, 12(2): 190-208. doi: 10.1080/17538947.2018.1425489.

[15] Feng Z, González VA, Amor R, Spearpoint M, Thomas J, Sacks R, Lovreglio R, CabreraGuerrero G (2020). An immersive virtual reality serious game to enhance earthquake behavioral responses and post-earthquake evacuation preparedness in buildings. Advanced Engineering Informatics, 45: 101118.

[16] Kristinsson KV (2015). Social Navigation in Unity 3D. M.Sc. Project Report, Reykjavík University.

[17] van den Berg J, Guy SJ, Lin M, Manocha D (2012). Reciprocal collision avoidance for multiple mobile robots. In IEEE International Conference on Robotics and Automation: pp. 1-16.

[18] Bohannon RW, Andrews AW (2011). Normal walking speed: a descriptive metaanalysis. Physiotherapy, 97(3): 182-189.

[19] Pilet J (2008). Augmented reality for non-rigid surfaces. Doctoral Dissertation. Available: http://www.hvrl.ics.keio.ac.jp/ julien/publi/PiletPhd.pdf.

[20] Fiala M (2007). Magic mirror system with hand-held and wearable augmentations. In 2007 IEEE Virtual Reality Conference: 251-254.

[21] Wu C, Yang Z, Xu Y, Zhao Y, Liu Y (2014). Human mobility enhances global positioning accuracy for mobile phone localization. IEEE Transactions on Parallel and Distributed Systems, 26(1): 131-141.

[22] Poon SL (2014). A dynamic approach to ASET/RSET assessment in performance based design. Procedia Engineering, 71: 173-181.

[23] Cooper LY (1983). A concept for estimating available safe egress time in fires. Fire Safety Journal, 5(2): 135-144.

[24] Alarifi AAS, Phylaktou HN, Andrews GE (2016). What kills people in a fire? heat or smoke? In the 9th Saudi Students Conference, University of Leeds. Available: https://eprints.whiterose.ac.uk/96795/1/Alarifi\%20SSC9\%20What\%20Kills\%20people\%20in $\% 20 \mathrm{a} \% 20$ Fire $\% 20$ Heat $\% 20$ or $\% 20$ Smoke $\% 20$ (final\%20version) $\% 20$-corrected.pdf. 


\section{APPENDIX A:}

STRESS DATA SURVEY USING GOOGLE FORM

\begin{tabular}{l} 
STRESS DATA \\
SURVEY ON \\
EVACUATION TEST \\
This is survey specially for evacuation test \\
for Final Year Project : AN IMMERSIVE \\
AUGMENTED REALITY SYSTEM - TO \\
STUDY THE EFFICIENT OF DYNAMIC EXIT \\
SIGNAGE: A CASE STUDY FOR KOE \\
BUILDING \\
Please choose your participant \\
number \\
Participant 1 \\
Participant 2 \\
Method of evacuation \\
Participant 3 \\
Scenario \\
Normal evacuation \\
with help of AR \\
Norticipant 4 \\
\hline Participant 5 \\
\hline
\end{tabular}

Please answer the following

question with the range of 5 level of

stress

1. Calm 1 - Somewhat Calm

3. - Normal

4-Somewhat Stress

5. Stress

Early confusion when experiencing

simulated drill during initial simulation

$$
\begin{array}{lllll}
1 & 2 & 3 & 4 & 5 \\
\bigcirc & \bigcirc & \bigcirc & \bigcirc & \bigcirc
\end{array}
$$

Finding the safest route

$\begin{array}{lllll}1 & 2 & 3 & 4 & 5 \\ \bigcirc & \bigcirc & \bigcirc & \bigcirc & \bigcirc\end{array}$

The agents running through hallway
$\begin{array}{lllll}1 & 2 & 3 & 4 & 5\end{array}$
00000

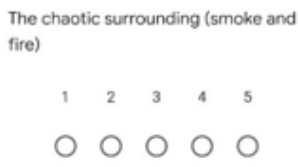

The chaotic surrounding (smoke and fire)
$\begin{array}{lllll}1 & 2 & 3 & 4 & 5\end{array}$
00000

Problem with detecting signage (For AR only)
00000

After the simulation
$\begin{array}{lllll}1 & 2 & 3 & 4 & 5\end{array}$
00000

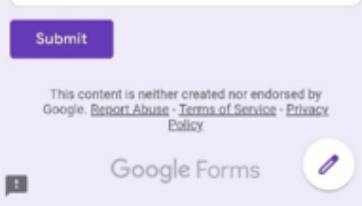




\section{APPENDIX B:}

RESULT FOR LEVEL OF STRESS SURVEY USING GOOGLE FORM

\begin{tabular}{|c|c|c|c|c|c|c|c|c|}
\hline $\begin{array}{c}\text { Please choose } \\
\text { your participant } \\
\text { number }\end{array}$ & Scenario & Method of evacuation & $\begin{array}{c}\text { Early } \\
\text { confusion } \\
\text { when } \\
\text { experiencing } \\
\text { simulated drill } \\
\text { during initial } \\
\text { simulation } \\
\end{array}$ & $\begin{array}{l}\text { Finding the } \\
\text { safest } \\
\text { route }\end{array}$ & $\begin{array}{l}\text { The } \\
\text { agents } \\
\text { running } \\
\text { through } \\
\text { hallway }\end{array}$ & $\begin{array}{l}\text { The chaotic } \\
\text { surrounding } \\
\text { (smoke and } \\
\text { fire) }\end{array}$ & $\begin{array}{c}\text { After the } \\
\text { simulation }\end{array}$ & $\begin{array}{l}\text { Problem } \\
\text { with } \\
\text { detecting } \\
\text { signage } \\
\text { (For AR } \\
\text { only) }\end{array}$ \\
\hline Participant 1 & Normal Scenario & Normal evacuation & 2 & 1 & 1 & 1 & 2 & \\
\hline Participant 1 & Normal Scenario & With help of AR & 1 & 1 & 2 & 1 & 2 & 1 \\
\hline Participant 1 & Low Visibility & Normal evacuation & 3 & 2 & 1 & 3 & 2 & \\
\hline Participant 1 & Low Visibility & With help of AR & 3 & 2 & 1 & 2 & 2 & 1 \\
\hline Participant 1 & Blocked Path & Normal evacuation & 4 & 5 & 2 & 5 & 3 & \\
\hline Participant 1 & Blocked Path & With help of AR & 3 & 2 & 2 & 2 & 2 & 2 \\
\hline Participant 1 & Jammed Path & Normal evacuation & 2 & 1 & 2 & 1 & 2 & \\
\hline Participant 1 & Jammed Path & With help of AR & 2 & 1 & 2 & 1 & 2 & 1 \\
\hline Participant 2 & Normal Scenario & Normal evacuation & 1 & 1 & 1 & 1 & 1 & \\
\hline Participant 2 & Normal Scenario & With help of AR & 1 & 1 & 1 & 1 & 1 & 1 \\
\hline Participant 2 & Low Visibility & Normal evacuation & 3 & 1 & 1 & 1 & 2 & \\
\hline Participant 2 & Low Visibility & With help of AR & 2 & 1 & 1 & 1 & 1 & 1 \\
\hline Participant 2 & Blocked Path & Normal evacuation & 3 & 5 & 1 & 2 & 2 & \\
\hline Participant 2 & Blocked Path & With help of AR & 3 & 1 & 1 & 1 & 2 & 2 \\
\hline Participant 2 & Jammed Path & Normal evacuation & 3 & 1 & 4 & 3 & 2 & \\
\hline Participant 2 & Jammed Path & With help of AR & 2 & 2 & 2 & 2 & 2 & 1 \\
\hline Participant 3 & Normal Scenario & Normal evacuation & 3 & 3 & 4 & 1 & 3 & \\
\hline
\end{tabular}

